\title{
褐炭液化重質物の収率と性状に及ぼす蒸留温度と 原料溶剂組成の影響
}

(キ-ワード 褐炭液化、原料溶剤、蒸留温度、蒸留残渣、重質液化物)

- 1994.6.24 受理一

日本褐炭液化株式会社*1 平 野 龍 夫 株式会社神戸製鋼所*2 大 隈 修

\section{1. 序}

溶剤中で石炭を液化する直接液化法に抢いては，系 内で溶剤を循環使用できることが，プロセス成立のた めの必須の要件である。一般に溶剤の回収は, 製品油 の分離を兼ねて液状生成物から蒸留によって行われる。 そのため, 生成液の蒸留条件は, 液化反応条件ととも に, 製品油と循環溶剤の性状を決定するプロセス開発 上の重要な因子となる。特に, 留出油と残渣を分離す る減圧蒸留の上限となる分画温度は, 溶剂および製品 油の沸点範囲を決定するのみならず，残渣および製品 油の収率と性状を決定し，プロセスの経済性に大きな 影響を及ぼす。

一段液化法においては, 蒸留は固液分離手段とも なっており，通常蒸留残渣は製品化されず熱分解によ る油分回収や，水素製造のためのガス化原料として利 用される ${ }^{1)}$ 。そのため, 製品収率および溶剂回収効率 を向上させるため，できるだけ高い分画温度が指向さ れるが，分画温度を高くするに従い残渣の抜き出し上 のハンドリング性や重縮合によるコーキングがプラン 卜運転上問題となり ${ }^{2)}$, おのずと分画温度に上限が存 在することになる。一方, 褐炭を対象として開発され た BCL (Brown coal Liquefaction) プロセスのような 二段液化法においては, 液化油収率の向上のためには 必ずしも笅しい蒸留は必要では無いものの, 蒸留残渣 の収率と性状は, 後流の溶剤脱灰および二次水添工程

*1 高砂研究所 兵庫県高砂市荒井町新浜 2-3-1 (神戸製鋼所高砂事業所内)

*2 技術開発本部化学・高分子研究所 神戸市西区高塚台 1 - 5 - 5
の効率に大きな影響を与える314)。

このように, 重質液化物である蒸留残渣の収率と性 状を決定する蒸留条件は, 直接液化プロセス開発上の 重要な課題であるにもかかわらず，その影響を明らか にした報告はほとんどみられない。本報告は，BCL プロセスの一次水添工程に扔ける液状生成物の蒸留条 件設定を最適化するための一環として，原料溶㓮や液 化反応条件の異なる液化生成物を用いて, 蒸留残渣の 収率と性状に与える蒸留温度と原料溶剤組成の影響を 調べ, 液化工程における蒸留温度を上げることによる 液化油収率の向上の可能性について検討したものであ る。また, 蒸留操作の前提となる残渣のハンドリング 性を粘度の観点から検討した。

\section{2. 実 験}

\section{1 液化実験}

豪州で乾燥された Morwell 炭を微粉砕し, 無水無 灰炭基準（以下 $\mathrm{maf}^{-} \mathrm{C}$ と略す）で, 重量比2.5倍量の 溶剂と混合, スラリー化し, $0.1 \mathrm{t} / \mathrm{d}$ の完全混合槽 3 槽よりなる連続装置 ${ }^{5}$ をを用いて酸化鉄/硫黄触媒の存 在下で液化した。触媒添加量は, すべての実験におい て鉄として maf-C あたり $3 \mathrm{wt} \%$ とし, $\mathrm{S} / \mathrm{Fe}$ 原子比 を 1.2 とした。溶剤として以下の 4 種を用いた。

(1)連続装置による Morwell 炭の液化実験で循環使 用された沸点 $180-420^{\circ} \mathrm{C}$ の留分 (Run-A, 以下溶剂留 分と呼ぶ), (2)沸点 $180-420^{\circ} \mathrm{C}$ に調製したクレオソート 油 (Run-B), (3)溶剤留分に同じく Morwell 炭の液化 によって得られた沸点 $420^{\circ} \mathrm{C}$ 以上の蒸留残渣 (CLB, Coal Liquid Bottom) を溶解したもの（Run-C, 以下 CLB 循環溶剂と呼ぶ), (4) CLB を溶剂留分とともに 
二次水添して得られた沸点 $250^{\circ} \mathrm{C}$ 以上の生成液 (Hydrogenated De-Ashed Oil, 以下 HDAO と略す) と CLB および溶剤留分を混合した BCL プロセスの一 次水添工程で用いる溶剂 (Run-D, 以下 BCL 溶剂と 呼ぶ)。本報告では(3) CLB 循環溶剤と(4) BCL 溶剂を あわせて，ボトム循環系溶剂と呼ぶ。Table 1 に液化 実験に用いた褐炭の性状を, Table 2 に各液化実験の 反応条件の詳細を示す。Table 3 に各実験に用いた溶 剤の組成とその成分の性状を示す。

\section{2 生成液の蒸留}

連続液化装置より得られた液状生成物を, ASTMD1160法に準拠した単蒸留法（系内圧 $10 \mathrm{mmHg}$ )に よって, 液温 (ボトム温度) $287-350^{\circ} \mathrm{C}$ で適宜分画し それぞれ蒸留残渣を回収した。このとき, 蒸留系の温 度として液相表面近傍のガス相の温度（以下, 表面温 度と呼ぶ）と, 系の上部のガス温（以下, ガス温と呼 ぶ）を測定した。また，Run-Aの試料については， 連続減圧蒸留系との対応をとるため, あらかじめ常圧

Table 1 Properties of Morwell coal

\begin{tabular}{|c|c|c|c|c|c|c|c|}
\hline \multicolumn{3}{|c|}{ Proximate Analysis [wt\%] } & \multicolumn{5}{|c|}{ Ultimate Analysis $[\mathrm{wt} \%$ on maf $\cdot \mathrm{C}]$} \\
\hline Moist. & Ash & V.M. & $\mathrm{C}$ & $\mathrm{H}$ & $\mathrm{N}$ & $\mathrm{S}$ & $O($ diff. $)$ \\
\hline 12.0 & 2.4 & 46.1 & 68.5 & 4.8 & 0.6 & 0.2 & 25.9 \\
\hline
\end{tabular}

Table 2 Liquefaction Conditions

\begin{tabular}{cccccl}
\hline Run & $\begin{array}{r}\text { Temp. } \\
{\left[{ }^{\circ} \mathrm{C}\right]}\end{array}$ & $\begin{array}{c}\text { Press. } \\
{[\mathrm{MPa}]}\end{array}$ & $\begin{array}{c}\theta_{\mathrm{NT}}{ }^{1)} \\
{[\mathrm{h}]}\end{array}$ & $\begin{array}{c}\text { Solv./Coal }{ }^{2)} \\
{[\mathrm{kg} / \mathrm{kg}-\mathrm{maf} \cdot \mathrm{C}]}\end{array}$ & Composition of solvent $^{3)}$ \\
\hline $\mathrm{A}$ & 430 & 14.7 & 1.0 & 2.5 & Solv.Fr-A \\
$\mathrm{B}$ & 430 & 14.7 & 0.33 & 2.5 & Solv.Fr-B \\
$\mathrm{C}$ & 430 & 14.7 & 1.0 & 2.5 & Solv.Fr-C/CLB-C $=4 / 1(\mathrm{wt} / \mathrm{wt})$ \\
$\mathrm{D}$ & 450 & 14.7 & 1.0 & 2.5 & Solv.Fr-D/CLB-D/HDAO=3/1/2(wt/wt/wt) \\
\hline
\end{tabular}

1) Nominal Reaction Time

2) Including CLB and/or HDAO

3) See Table 3

Other Conditions ; catalyst : $\mathrm{Fe}_{2} \mathrm{O}_{3} 3 \mathrm{wt} \%$ on maf $\cdot \mathrm{C}$ as $\mathrm{Fe}, \mathrm{S} / \mathrm{Fe}: 1.2$ (atomic ratio)

$\mathrm{H}_{2}$ feed: $10 \mathrm{wt} \%$ on maf $\cdot \mathrm{C}$

Table 3 Properties of Feed-Solvent Components

\begin{tabular}{|c|c|c|c|c|c|c|c|c|c|c|c|}
\hline \multicolumn{2}{|l|}{ Components } & \multicolumn{5}{|c|}{ Ultimate Analysis [wt\%] } & \multicolumn{2}{|c|}{ Atomic Ratio } & \multicolumn{3}{|c|}{ Structural Parameter } \\
\hline & & $\mathrm{C}$ & $\mathrm{H}$ & $\mathrm{N}$ & $\mathrm{S}$ & $O($ diff. $)$ & $\mathrm{H} / \mathrm{C}$ & $\mathrm{O} / \mathrm{C}$ & $\mathrm{fa}$ & $\mathrm{Hau} / \mathrm{Ca}$ & $\operatorname{Ln}$ \\
\hline Solvent & $A^{1)}$ & 88.2 & 7.6 & 0.7 & 0.2 & 3.2 & 1.03 & 0.027 & 0.72 & 0.88 & 2.03 \\
\hline Fraction & $\mathrm{B}^{2)}$ & 91.5 & 6.2 & 1.2 & 0.5 & 0.7 & 0.81 & 0.006 & 0.90 & 0.79 & 1.09 \\
\hline (b.p.180 & $C^{2)}$ & 87.7 & 7.9 & 0.6 & 0.2 & 3.7 & 1.07 & 0.031 & 0.69 & 0.90 & 2.24 \\
\hline$\left.\sim 420^{\circ} \mathrm{C}\right)$ & $D^{2)}$ & 88.8 & 8.6 & 0.4 & 0.2 & 2.0 & 1.15 & 0.017 & 0.57 & 0.83 & 2.61 \\
\hline $\mathrm{CLB}^{3)}$ & $\mathrm{C}$ & 86.1 & 6.1 & 1.1 & 0.2 & 6.5 & 0.85 & 0.057 & 0.70 & 0.70 & 2.06 \\
\hline (b.p. $\left.>420^{\circ} \mathrm{C}\right)$ & $\mathrm{D}$ & 88.9 & 5.9 & 0.7 & 0.2 & 4.3 & 0.80 & 0.036 & 0.78 & 0.66 & 1.89 \\
\hline $\begin{array}{l}\mathrm{HDAO}^{4)} \\
\left(\mathrm{b} . \mathrm{p} .>250^{\circ} \mathrm{C}\right)\end{array}$ & $\mathrm{D}$ & 89.9 & 8.5 & 0.4 & 0.6 & 0.6 & 1.12 & 0.001 & 0.59 & 0.78 & 2.69 \\
\hline
\end{tabular}

1) Recycling solvent in primary hydrogenation (liquefaction) section

2) Creosote oil

3) Analyzed on pyridine solubles of CLB.

CLB-C and D contained $10.7 \mathrm{wt} \%$ and $12.2 \mathrm{wt} \%$ of ash, respectively.

4) Containing $22.0 \mathrm{wt} \%$ of bottom ( b.p. $>420^{\circ} \mathrm{C}$ ) and $0.3 \mathrm{wt} \%$ of ash. 
Table 4 Distillation Conditions

\begin{tabular}{|c|c|c|c|c|c|c|c|c|}
\hline \multirow{4}{*}{$\begin{array}{l}\text { Pressure } \\
10 \mathrm{mmHg}\end{array}$} & \multicolumn{2}{|l|}{ Measuring Point } & \multicolumn{6}{|c|}{ Cut off Temperature $\left[{ }^{\circ} \mathrm{C}\right]$} \\
\hline & \multirow{3}{*}{$\begin{array}{l}\text { bottom } \\
\text { surface }^{2)}\end{array}$} & \multicolumn{4}{|c|}{ ASTM-D1160 } & \multicolumn{3}{|c|}{ Flash $^{1)}$} \\
\hline & & 287 & 305 & 323 & 350 & - & - & - \\
\hline & & 261 & 274 & 289 & 315 & 282 & 305 & 323 \\
\hline \multirow[t]{2}{*}{$760 \mathrm{mmHg}^{3)}$} & bottom & 450 & 472 & 494 & 526 & - & - & - \\
\hline & surface & 420 & 435 & 453 & 484 & 445 & 472 & 494 \\
\hline
\end{tabular}

1) Flashing Conditions : Pressure was reduced from $0.2 \mathrm{MPa}$ to $10 \mathrm{mmHg}$. The volume of feed was $0.1 \mathrm{~L} / \mathrm{h}$.

2) Temp. of vapor on liquid surface

3) Reduced pressure from $10 \mathrm{mmHg}$ to $760 \mathrm{mmHg}$ by ASTM-D2892

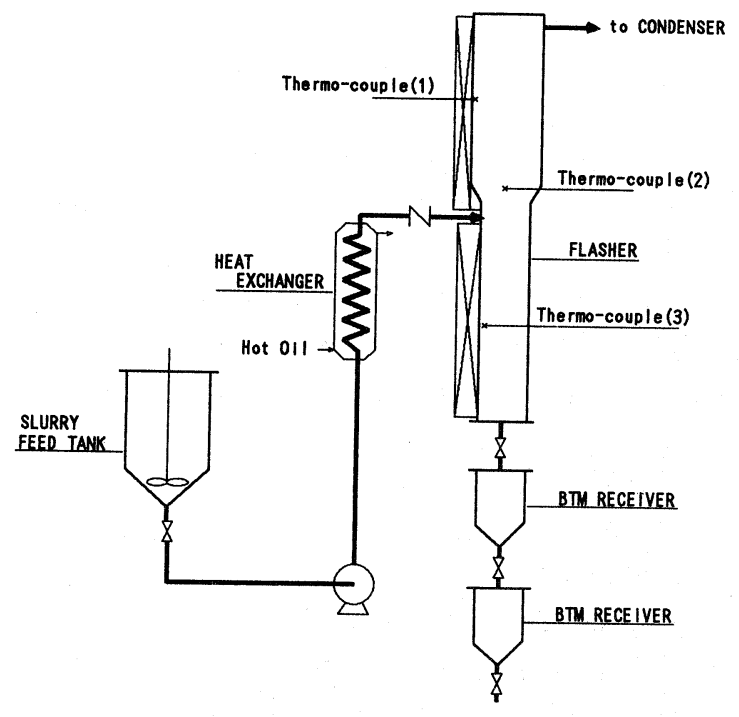

Fig. 1 Apparatus of Flash Distillation

換算で $250^{\circ} \mathrm{C}$ 以下の軽沸留分を留去した後, Fig. 1 に 示す小型連続フラッシュ蒸留装置を用い, 系内圧

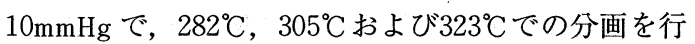
い, 蒸留法の違いの影響を検討した。Table 4 に単蒸 留およびフラッシュ蒸留の条件とASTM-D2892に基 づき常圧に換算した温度を示す。

\section{3 蒸留残渣の分析および流動性の測定}

単蒸留およびフラッシュ蒸留で得た残渣は, 工業分 析, 元素分析, 溶剤分別に供した。さらに, 各溶剤分 別成分について，元素分析，Brown-Ladner 法による 構造解析を行い構造指数を求めるとともに, GPCに よって分子量を測定した。また, 留出成分を採取し, FD/MSによる成分の同定を行った。

さらに，蒸留による油分回収の前提となる残渣の八

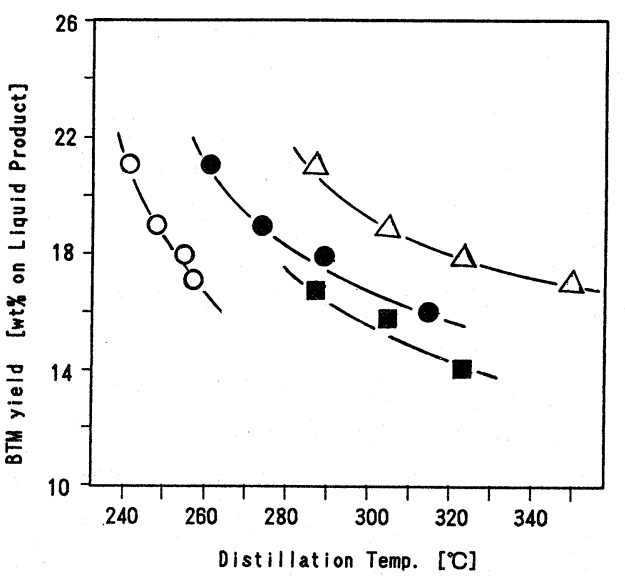

Fig.2 Relationship between Distillation Temperature and Bottom (BTM) Yield ASTM-D1160 ; $\triangle$ Bottom Temp., Surface Vapor Temp., $\bigcirc$ Gas Temp.

Flash Distillation ; Temp. of Vapor Phase (Thermo Couple(2) in Fig. 1)

ンドリング性を検討するため, レオメーターによる粘 度の測定を行った。

\section{3. 結果と考察}

3.1 蒸留温度の残渣の収率と性状に与える影響

3.1 .1 単蒸留とフラッシュ蒸留の温度の比較

RUN-A の生成液を, 単蒸留およびフラッシュ蒸留 で蒸留した場合の, 蒸留温度と残渣の収率との関係を Fig. 2 に示す。単蒸留の温度制御は, 温度の安定性と 制御が容易であることより液温（ボトム温度）で実施 したが，Fig. 2 に示したようにガス温，表面温度，ボ トム温度でそれぞれ $30^{\circ} \mathrm{C}$ 程度の差が存在した。これは， 
褐炭液化生成液が非常に広い沸点範囲の混合物より構 成され，液温の上昇とともに徐々に留出していくため, ガス温度では蒸留器上部での熱損失による温度の低下 が大きく, ボトム温度は実際留出している成分の沸点 より高温になる度合いが大きいためである。したがっ て, 実際に蒸発している成分に直接接触している液相 表面近傍の温度を蒸留温度として採用し，以下の議論 に用いた。一方, フラッシュ蒸留では, Fig. 1 の温度 計 (2)で測定されるフラッシュ部分よりの上昇蒸気の 温度を蒸留温度として採用した。しかし, Fig. 2 に示 したように, 回分操作である単蒸留の表面温度と, 平 衡に近い状態にあると考えられるフラッシュ蒸留では 同じ蒸気温度でもフラッシュ蒸留の方が残渣の収率が 小さかった。この結果より, 通常粗分離に用いられる フラッシュ蒸留と比べても単蒸留の分離度は低く ${ }^{6)}$, なお液状生成物に対して数\%の留出油か残渣中に残つ ていることがわかる。したがって，以下の議論で用い る単蒸留の蒸留温度では, かなりの蒸留温度以下の沸 点を持つ留分か残つていることになる。

\section{1 .2 蒸留温度と残渣の収率と性状の変化 (Run-A)}

Table 5 に液化反応時の気相水素消費量とガス状生 成物および液状生成物を maf-C あたりの収率 5 (7) 7 とし て求めた結果を示す。液状生成物の収率は原料溶剂お よび液状生成物をそれぞれ単蒸留によつて分画し，原 料中の溶剤留分 (b.p. 180-420ㄷ) 抢よびボトム分 (b.p. $>420^{\circ} \mathrm{C}$ ) が重量として変化しないものとして生 成物より引き去って求めた ${ }^{5) 7}$ 。

Table 6 に蒸留温度を変化させた時の残渣㧍よびそ の溶剤分別成分の収率を示す。原料溶剤として一次水 添溶剂留分を用いた RUN-A の生成液では, 単蒸留 $(10 \mathrm{mmHg})$ での蒸留温度を $261^{\circ} \mathrm{C}$ から $315^{\circ} \mathrm{C}$ に上げる ことによって, 留出油は生成液基準で約 $5 \mathrm{wt} \%$ 増加 した。この結果は, ASTM-D2892による常圧換算で

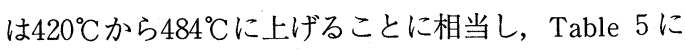
示した maf-C 基準の Run-A の留出油収率では，ガス 状生成物および死分を補正すると約 $18 \mathrm{wt} \%$ の留出油 の増加となり, $21 \mathrm{wt} \%$ の収率が $39 \mathrm{wt} \%$ に増加するこ とになる。また, フラッシュ蒸留の結果によれば, 蒸 留温度を上げることでさらに液化油（留出油）の回収 率の増加が可能と考えられ，いかに液化油回収率の向 上に蒸留温度を上げることが有効かがわかる。

このとき, Run-A の蒸留残渣中に残った溶剤分別 成分は, HI 成分 (HI-BS, BI-PS, PS 各成分の和) に わずかな増加傾向が認められたものの, PI 成分とと もにその収率はほぼ一定であった。一方，BI 成分 （BI-PS と PI 成分の和）は蒸留温度とともに増加した。 これは, 蒸留温度の上昇とともに HS 成分が留出し, HI-BS 成分が重質化して BI-PS 成分に変化したこと を示している。 $260^{\circ} \mathrm{C}$ 以上で留出した HS 成分は, Fig. 3 に示す FD/MS 測定によって, 分子量200-300 の $\mathrm{C}_{16}-\mathrm{C}_{18}$ の3-4環芳香族化合物とそのアルキル誘導 体およびパラフィンが主成分であることがわかった。 一方, $323^{\circ} \mathrm{C} て ゙ も$ 留出しなかった HS 成分は, 分子量 300 以上の多環芳香族化合物と考えられた ${ }^{8)}$ 。また, Table 7 に示す溶剤分別成分の分析結果より, 高温で CLB 中に残った HS 成分ほど H/C 值が高く $\mathrm{fa}$ 值が低 い傾向が認められ, 蒸留温度を上げていくと低分子で 芳香族性の高い成分から留出していくことが示唆され る。このとき $\mathrm{HI}-\mathrm{BS}$ 成分の性状は, 温度の上昇に伴 う $\mathrm{Hau} / \mathrm{Ca}$ 值の減少と $\mathrm{Ln}$ 值および Mn 值の増加より, 芳香環が発達し，かつ，側鎖も長い重質化したものと なっていることが示唆された。蒸留温度の上昇による BI-PS 成分の性状は, Table 7 に示したようにfa 值, $\mathrm{Ln}$ 值および Mn 值の増加と $\mathrm{Hau} / \mathrm{Ca}$ 值の減少が認め られ, HI-BS 成分と同様に, 温度の上昇による重質 化が認められた。

以上の結果より, 留出油である循環溶剤留分のみを

Table 5 Yield of Liquefaction Products

\begin{tabular}{ccrrrrrrc}
\hline & \multicolumn{7}{c}{ Product Yield $[\mathrm{wt} \%$ on maf $\cdot \mathrm{C}]$} \\
\cline { 2 - 8 } Run & $\mathrm{CLB}^{1)}$ & Solv. $^{2)}$ & Naph. $^{3)}$ & $\mathrm{H}_{2} \mathrm{O}$ & $\mathrm{C}_{1} \sim \mathrm{C}_{4}$ & $\mathrm{CO}+\mathrm{CO}_{2}$ & $\Delta \mathrm{H}_{2}$ & distillate $^{4)}$ \\
\hline $\mathrm{A}$ & 58.6 & 16.6 & 4.4 & 8.0 & 4.3 & 10.8 & -2.7 & 21.0 \\
$\mathrm{~B}$ & 59.6 & 9.2 & 9.0 & 10.4 & 2.5 & 11.8 & -2.5 & 18.2 \\
$\mathrm{C}$ & 35.6 & 23.1 & 12.6 & 16.6 & 4.8 & 12.1 & -4.8 & 35.7 \\
$\mathrm{D}$ & 28.4 & 20.9 & 17.2 & 12.6 & 8.8 & 16.2 & -4.1 & 38.1 \\
\hline
\end{tabular}

1) Coal liquid bottom (residue), b.p. $>420{ }^{\circ} \mathrm{C} \quad$ 2) Solvent fraction, b.p $180 \sim 420^{\circ} \mathrm{C}$

3) Naphtha fraction, b.p $<180^{\circ} \mathrm{C} \quad$ 4) Total distillate (Solv. + Naph.), b.p. $<420^{\circ} \mathrm{C}$ 
Table 6 Effects of Distillation Temperature on Yield of Bottom and Solvent Extracts

\begin{tabular}{|c|c|c|c|c|c|c|c|c|c|c|}
\hline \multirow[t]{2}{*}{ Run } & \multirow[t]{2}{*}{ Distillation } & \multirow{2}{*}{$\begin{array}{l}\text { Temp. } \\
\left({ }^{\circ} \mathrm{C} \text { at } 10 \mathrm{mmHg}\right)\end{array}$} & \multicolumn{8}{|c|}{$\begin{array}{c}\text { Yield (wt\% on Liquid Product) } \\
\text { Solvent Extracts }\end{array}$} \\
\hline & & & Bottom $^{3)}$ & $\mathrm{HI}^{4)}$ & $\mathrm{BI}^{5)}$ & HS & HI-BS & BI-PS & $\mathrm{PI}^{3)}$ & Ash \\
\hline A & ASTM-D1160 & $\begin{array}{l}261 \\
274 \\
289 \\
315\end{array}$ & $\begin{array}{l}21.1 \\
18.9 \\
17.9 \\
16.1\end{array}$ & $\begin{array}{l}14.7 \\
14.4 \\
15.3 \\
15.5\end{array}$ & $\begin{array}{r}8.6 \\
8.8 \\
9.5 \\
11.4\end{array}$ & $\begin{array}{l}6.4 \\
4.5 \\
2.6 \\
0.6\end{array}$ & $\begin{array}{l}6.1 \\
5.6 \\
5.8 \\
4.1\end{array}$ & $\begin{array}{l}6.1 \\
6.5 \\
7.1 \\
9.1\end{array}$ & $\begin{array}{l}2.4 \\
2.3 \\
2.4 \\
2.3\end{array}$ & $\begin{array}{l}2.4 \\
2.3 \\
2.4 \\
2.3\end{array}$ \\
\hline A & Flash $^{2)}$ & $\begin{array}{l}287 \\
305 \\
323\end{array}$ & $\begin{array}{l}16.7 \\
15.8 \\
14.1\end{array}$ & $\begin{array}{l}13.2 \\
14.1 \\
13.9\end{array}$ & $\begin{array}{r}8.5 \\
9.2 \\
10.8\end{array}$ & $\begin{array}{l}3.5 \\
1.7 \\
0.2\end{array}$ & $\begin{array}{l}4.7 \\
4.9 \\
3.1 \\
\end{array}$ & $\begin{array}{l}6.4 \\
7.1 \\
8.3 \\
\end{array}$ & $\begin{array}{l}2.1 \\
2.1 \\
2.5\end{array}$ & $\begin{array}{l}2.0 \\
2.1 \\
2.5\end{array}$ \\
\hline B & ASTM-D $1160^{1)}$ & $\begin{array}{l}261 \\
274 \\
289 \\
315 \\
\end{array}$ & $\begin{array}{l}21.1 \\
18.9 \\
17.9 \\
16.4\end{array}$ & $\begin{array}{l}14.7 \\
14.4 \\
15.3 \\
16.2\end{array}$ & $\begin{array}{l}8.6 \\
9.3 \\
9.2 \\
9.4\end{array}$ & $\begin{array}{l}6.4 \\
4.5 \\
2.6 \\
0.2\end{array}$ & $\begin{array}{l}6.1 \\
5.1 \\
6.1 \\
6.8\end{array}$ & $\begin{array}{l}6.1 \\
7.3 \\
7.1 \\
7.5\end{array}$ & $\begin{array}{l}2.4 \\
2.1 \\
2.1 \\
1.9\end{array}$ & $\begin{array}{l}2.1 \\
2.0 \\
2.0 \\
1.8\end{array}$ \\
\hline $\mathrm{C}$ & ASTM-D11601) & $\begin{array}{l}261 \\
274 \\
289 \\
315\end{array}$ & $\begin{array}{l}33.1 \\
32.5 \\
28.8 \\
25.2\end{array}$ & $\begin{array}{l}25.0 \\
25.0 \\
24.3 \\
21.6\end{array}$ & $\begin{array}{l}13.5 \\
13.8 \\
13.8 \\
13.0\end{array}$ & $\begin{array}{l}8.1 \\
7.5 \\
4.5 \\
3.6\end{array}$ & $\begin{array}{r}11.5 \\
11.2 \\
10.5 \\
8.3\end{array}$ & $\begin{array}{l}9.3 \\
9.3 \\
9.3 \\
9.1\end{array}$ & $\begin{array}{l}4.2 \\
4.5 \\
4.5 \\
3.9\end{array}$ & $\begin{array}{l}4.0 \\
4.3 \\
4.3 \\
3.9\end{array}$ \\
\hline $\mathrm{D}$ & ASTM-D1160") & $\begin{array}{l}261 \\
315\end{array}$ & $\begin{array}{l}35.1 \\
26.3\end{array}$ & $\begin{array}{l}24.0 \\
23.4\end{array}$ & $\begin{array}{l}11.9 \\
11.8\end{array}$ & $\begin{array}{r}11.1 \\
2.9\end{array}$ & $\begin{array}{l}12.1 \\
11.6\end{array}$ & $\begin{array}{l}6.4 \\
6.3\end{array}$ & $\begin{array}{l}5.5 \\
5.5\end{array}$ & $\begin{array}{l}4.3 \\
4.5\end{array}$ \\
\hline
\end{tabular}

1) Surface vapor temperature

2) Vapor temperature

3) Containing ash originated from catalyst and ash in coal

4) Hexane solubles : (HI-BS) + (BI-PS) + (PI)

5) Benzene solubles: (BI-PS) + (PI)

Table 7 Properties of Solvent Extracts in Distillation Bottom

\begin{tabular}{|c|c|c|c|c|c|c|c|c|c|c|c|c|c|c|c|c|}
\hline \multirow{2}{*}{$\begin{array}{c}\text { Run } \\
\text { Distillation }\end{array}$} & \multirow{2}{*}{ Temp. } & \multicolumn{5}{|c|}{$\mathrm{H} \mathrm{S}$} & \multicolumn{5}{|c|}{$\mathrm{H} \mathrm{I}-\mathrm{B} \mathrm{S}$} & \multicolumn{5}{|c|}{$\mathrm{BI}-\mathrm{PS}$} \\
\hline & & $\mathrm{H} / \mathrm{C}$ & fa & $\mathrm{Hau} / \mathrm{Ca}$ & Ln & $\mathrm{Mn}^{1)}$ & $\mathrm{H} / \mathrm{C}$ & $\mathrm{fa}$ & $\mathrm{Hau} / \mathrm{Ca}$ & $\operatorname{Ln}$ & $\mathrm{Mn}^{2)}$ & $\mathrm{H} / \mathrm{C}$ & $\mathrm{fa}$ & $\mathrm{Hau} / \mathrm{Ca}$ & $\operatorname{Ln}$ & $\mathrm{Mn}^{2)}$ \\
\hline A & 261 & 1.01 & 0.71 & 0.74 & 2.53 & 372 & 0.90 & 0.73 & 0.78 & 1.81 & 600 & 0.75 & 0.78 & 0.71 & 2.18 & 813 \\
\hline ASTM- & 274 & 1.01 & 0.74 & 0.75 & 2.54 & - & 0.91 & 0.72 & 0.79 & 1.91 & - & 0.74 & 0.79 & 0.70 & 1.94 & - \\
\hline \multirow[t]{2}{*}{ D1160 } & 289 & 1.03 & 0.73 & 0.75 & 2.53 & - & 0.92 & 0.70 & 0.77 & 1.96 & - & 0.73 & 0.81 & 0.68 & 2.00 & - \\
\hline & 315 & 1.04 & 0.69 & 0.75 & 2.50 & 411 & 0.91 & 0.71 & 0.73 & 2.50 & 677 & 0.74 & 0.81 & 0.67 & 2.18 & 959 \\
\hline A & 287 & 1.03 & 0.72 & 0.76 & 2.48 & 385 & 0.92 & 0.71 & 0.77 & 2.05 & 618 & 0.73 & 0.79 & 0.69 & 2.03 & 787 \\
\hline \multirow[t]{2}{*}{ Flash } & 305 & 1.02 & 0.68 & 0.76 & 2.47 & 372 & 0.92 & 0.71 & 0.77 & 2.06 & 611 & 0.73 & 0.79 & 0.68 & 2.03 & 851 \\
\hline & 323 & 1.04 & 0.61 & 0.76 & 2.51 & 428 & 0.91 & 0.69 & 0.66 & 2.73 & 691 & 0.74 & 0.83 & 0.73 & 2.05 & 935 \\
\hline B & 261 & & & & & & 0.89 & 0.73 & 0.78 & 1.81 & 452 & 0.75 & 0.78 & 0.71 & 2.18 & 548 \\
\hline $\begin{array}{l}\text { ASTM- } \\
\text { D1160 }\end{array}$ & 315 & & See & Table & 8 & & 0.94 & 0.69 & 0.77 & 2.00 & 489 & 0.76 & 0.78 & 0.68 & 2.76 & 598 \\
\hline C & 261 & & & & & & 0.92 & 0.71 & 0.79 & 1.93 & 682 & 0.76 & 0.78 & 0.70 & 1.99 & 935 \\
\hline $\begin{array}{l}\text { ASTM- } \\
\text { D1160 }\end{array}$ & 315 & & See & Table & 8 & & 0.92 & 0.71 & 0.74 & 2.03 & 637 & 0.76 & 0.88 & 0.64 & 2.41 & 959 \\
\hline D & 261 & & & & & & 0.84 & 0.75 & 0.70 & 1.76 & 611 & 0.71 & 0.86 & 0.68 & 2.19 & 961 \\
\hline $\begin{array}{c}\text { ASTM- } \\
\text { D1160 }\end{array}$ & 315 & & See & Table & 8 & & 0.84 & 0.77 & 0.69 & 1.83 & 600 & 0.70 & 0.84 & 0.65 & 2.35 & 975 \\
\hline
\end{tabular}

1) Average molecular weight measured by $\mathrm{FD} / \mathrm{MS}$

2) Average molecular weight measured by GPC 

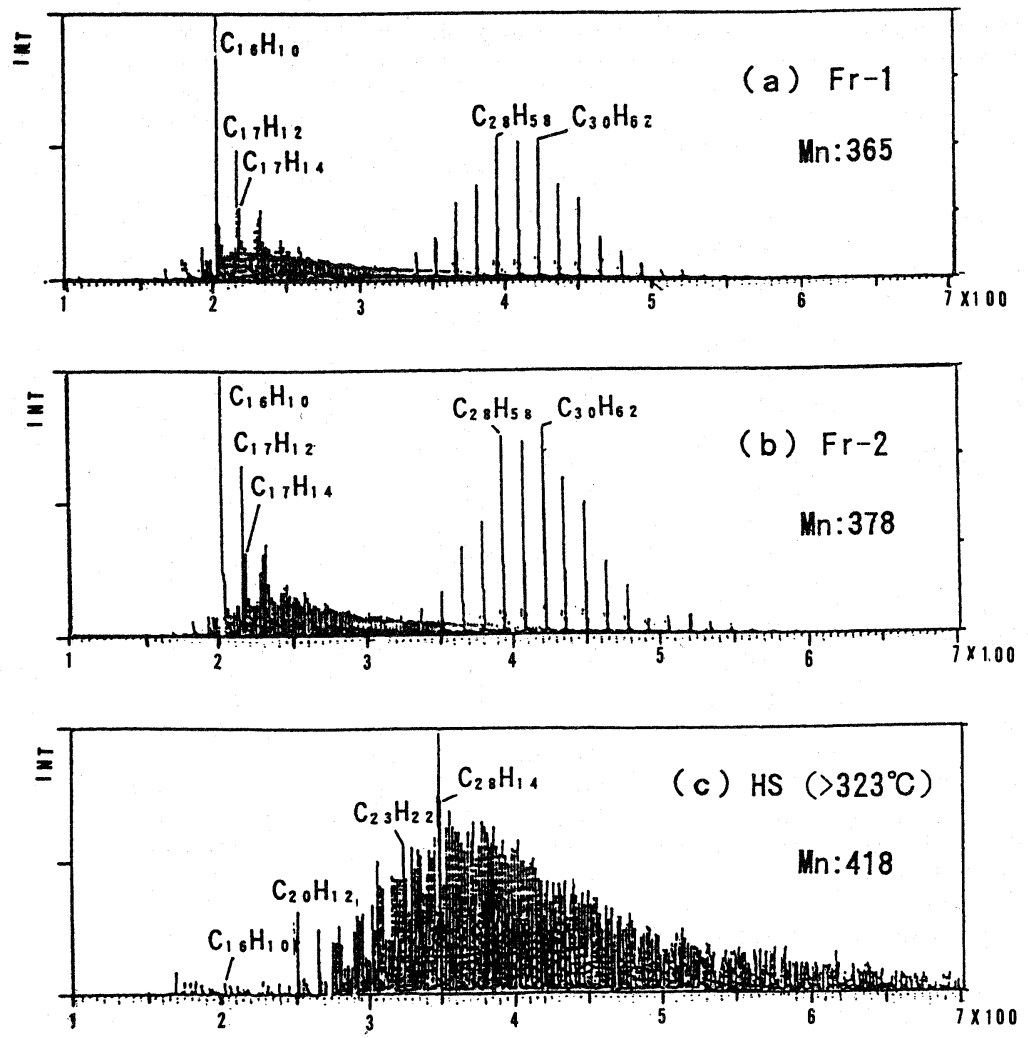

Fig.3 Analysis of Hexane Solubles (HS) by FD/MS (Run A)

(a) : Distillate of temperature range from $260^{\circ} \mathrm{C}$ to $273^{\circ} \mathrm{C}$ at $10 \mathrm{mmHg}$

(b) : Distillate of temperature range from $273^{\circ} \mathrm{C}$ to $287^{\circ} \mathrm{C}$ at $10 \mathrm{mmHg}$

(c) : Hexane soluble in bottom at $323^{\circ} \mathrm{C}, 10 \mathrm{mmHg}$

用いて褐炭を液化した生成液（Run-A）においては，

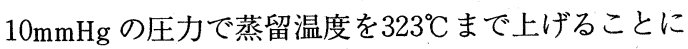
よつて HS 成分のほとんどを留出油として回収でき, 著しく液化油収率を向上させうるものの，一方で，わ ずかではあるが蒸留残渣の重質化が認められ, HI-BS 成分の BI-PS への移行が起こることが明らかとなっ た。したがって，さらに蒸留条件を厳しくすることに よって, 液化油 (留出油) 回収率の向上をはかるには, この残渣の重質化の影響を考慮し，蒸留塔の操作性の 観点からプロセスにとって最適な条件を選定する必要 があると考えられる。

\section{2 原料溶剂および液化条件の影響}

Table 5 および 6 に示したように，ボトム循環溶剤 を用いて液化した場合 (ボトム循環系 Run-C, D), 留 出油のみを溶剂とした場合（溶剂留分系 Run-A, B） に比べて，原料溶剤中のボトムの影響で液化油収率は 高くなるものの, 液化生成液中のボトム濃度は高く
なっている。また Run-D が Run-C に比べて液化油収 率が高く, かつ, 生成液中のボトム濃度が高いのも原 料溶剤中のボトム濃度が高いためである。そのため, Table 6 に示すように, 蒸留温度を上げた時の残渣の 収率の減少度合もボトム循環系の方が溶剤留分系より 大きく, 液化油 (留出油) の回収率の増加効果が一層 大きいことがわかった。しかし，いずれの Runでも 蒸留温度の上昇とともに残渣の収率が減少し, 液化油 (留出油) の回収率が著しく向上することは共通であ り, 留出する成分が HS 成分であることに変わりはな かった。一方, 溶剂分別成分の収率からみると原料溶 剂および液化反応条件による差異が認められた。溶剂 留分系（Run-A）では，既に述べたようにHS 成分の 減少と同時にBI-PS 成分の増加が認められたが, 溶 剤に水素供与性のないクレオソート油を用い短時間

(20分) で液化した Run-B では，高温 $\left(289^{\circ} \mathrm{C}\right.$ 以上) で HI-BS および BI-PS 両成分の増加が認められ, 
Run-A に比べ蒸留によってさらに重質化しやすいボ トムが生成していることがわかっだ)。これに対して ボトム循環系（Run-C, D）ではいずれも蒸留温度の 上昇による BI-PS 成分の増加は認められず, HI-BS 成分の減少によって HI 成分が減少する結果となった。 また，溶剤留分系（Run-A, B）に比べて高温での HS 成分の残留量が多いことがわかった。これらの溶剤分 別成分の変化は，ボトム循環系では蒸留温度を上げる ことによって残渣の軽質化が起こっていることを示し ている。Table 8 に蒸留温度を上げていった時の留出 成分およびHS成分の分析結果を示す。Table 7 に示 した HI-BS およびBI-PS 成分の構造指数の差は小さ く，これらの指数によって表される HI-BS および BI-PS 成分の性状に対する原料溶剂および反応条件の 影響は小さいものと考えられた。しかし, Table 7 に 示したRun-A の HS 成分の分析值および Table 8 の 結果から, 溶剂留分系 (Run-A, B) では高温で留出 する HS 成分ほど fa 值が低いのに対して, ボトム循 環系（Run-C, D）は逆に高くなっていた。一方, GPC による溶剂分別成分の平均数分子量（Table 7) および分子量分布の変化 (Fig. 4) から溶剂留分系 (Run-A, B) では HI-BS, BI-PS の両成分とも蒸留 温度の上昇とともに分子量か増加したのに対して，ボ トム循環系（Run-C, D）では, HI-BS 成分では逆に 分子量が小さくなり, BI-PS 成分の分子量は大きく なったものの, その増加の割合は小さかったことがわ かる。これらの結果は, 溶剂留分系 (Run-A, B) は HI-BS 成分が蒸留温度が上がると高分子量化（重質 化）するのに対して，ボトム循環系（Run-C, D）で は逆に HI-BS 成分の減少に伴う残渣の軽質化ととも
に HI-BS 成分そのものの軽質化も起こっていること を示している。これは, ボトムを含む溶郕で液化して 得られる重質物は, 重質物が褐炭から直接生成する留 出油のみを溶剤とした場合に比べて，より熱的に安定 であり，特に BCL 溶剤ではボトム中に高分子で部分 的に水素化の進んだ成分に富んだ成分が多く10)，同 一の蒸留温度では留出しにくいオイル (HS 成分), アスファルテン（HI-BS 成分）であるためと考えら れた。そのため, 留出油のみを溶剤とした場合 HS 成

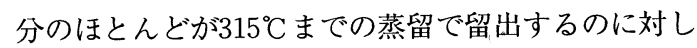
て，ボトム循環溶剤を用いた場合かなりの HS 成分が

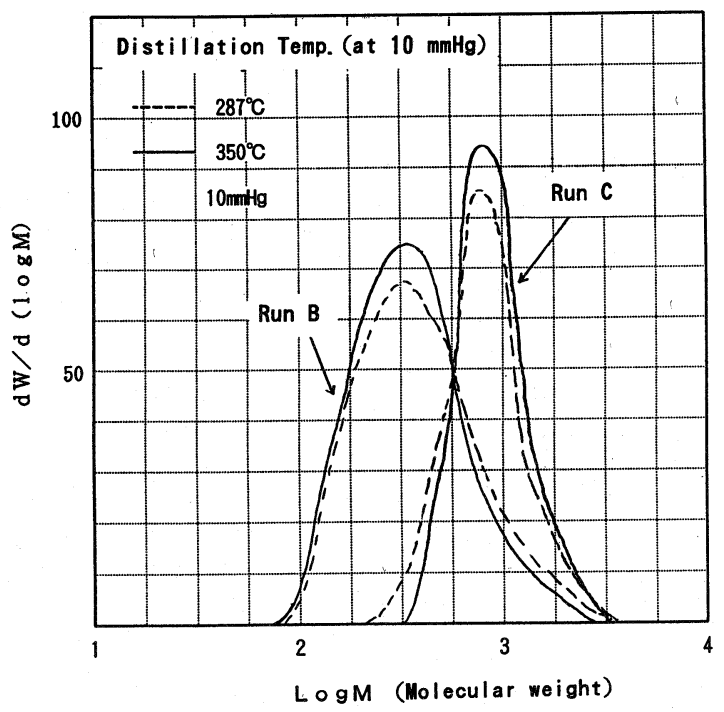

Fig.4 Molecular Weight Distribution of $\mathrm{HI}-\mathrm{BS}$ by GPC Analysis (Run B and C)

Table 8 Properties of Distillates and Hexane Solubles in Bottom (Run B. C and D)

\begin{tabular}{|c|c|c|c|c|c|c|c|c|c|c|c|}
\hline \multirow[t]{2}{*}{ Run } & \multirow[t]{2}{*}{ Fraction } & \multirow{2}{*}{$\begin{array}{l}\text { Cut off Temp. } \\
\left({ }^{\circ} \mathrm{C} \text { at } 10 \mathrm{mmHg}\right)\end{array}$} & \multicolumn{2}{|c|}{ Atomic Ratio } & \multicolumn{3}{|c|}{${ }^{1} \mathrm{H}-\mathrm{NMR}$} & \multicolumn{3}{|c|}{ Structural Parameter } & \multirow[b]{2}{*}{$\mathrm{Mn}^{1)}$} \\
\hline & & & $\mathrm{O} / \mathrm{C}$ & $\mathrm{H} / \mathrm{C}$ & $\mathrm{Ha}$ & $\mathrm{H} \alpha$ & Ho & $\mathrm{fa}$ & $\mathrm{Hau} / \mathrm{Ca}$ & Ln & \\
\hline \multirow[t]{3}{*}{$\mathrm{B}$} & $\mathrm{Fr}-1$ & $261 \sim 289$ & 0.029 & 0.99 & 40.42 & 26.64 & 32.94 & 0.70 & 0.803 & 2.236 & 352 \\
\hline & $\mathrm{Fr}-2$ & $289 \sim 315$ & 0.036 & 1.02 & 34.59 & 22.01 & 43.40 & 0.67 & 0.751 & 2.972 & 348 \\
\hline & HS & $315+$ & 0.029 & 1.05 & 30.00 & 30.00 & 40.00 & 0.63 & 0.787 & 2.333 & 389 \\
\hline \multirow[t]{3}{*}{$\mathrm{C}$} & $\mathrm{Fr}-1$ & $261 \sim 289$ & 0.016 & 1.06 & 33.74 & 23.57 & 42.68 & 0.65 & 0.761 & 2.811 & - \\
\hline & $\mathrm{Fr}-2$ & $289 \sim 315$ & 0.018 & 1.01 & 34.21 & 25.44 & 40.35 & 0.67 & 0.727 & 2.586 & - \\
\hline & HS & $315+$ & 0.007 & 0.94 & 41.34 & 32.15 & 26.51 & 0.72 & 0.758 & 1.825 & - \\
\hline \multirow[t]{3}{*}{$\mathrm{D}$} & $\mathrm{Fr}-1$ & $261 \sim 289$ & 0.017 & 0.98 & 36.36 & 27.44 & 36.19 & 0.69 & 0.736 & 2.319 & 367 \\
\hline & Fr-2 & $289 \sim 315$ & 0.023 & 0.97 & 35.73 & 27.96 & 36.31 & 0.69 & 0.730 & 2.299 & 387 \\
\hline & HS & $315+$ & 0.006 & 0.90 & 45.56 & 24.34 & 30.10 & 0.75 & 0.700 & 2.237 & 422 \\
\hline
\end{tabular}

1) Average molecular weight measured by $\mathrm{FD} / \mathrm{MS}$ 
残渣中に残ることになったものであろう。また，溶剤 循環系では HS 成分の留出ともに重質化が起こったの に対して，この残渣中の HS 成分およびアスファルテ ン（HI-BS 成分）の部分の水素供与性の作用 ${ }^{11)}$ に よって, ボトム循環系では蒸留温度を上げても重質化 が起こらず，逆に HI-BS 成分がHS 成分に転化し， HI-BS 成分そのものの軽質化が起こったものと考え られる。これは, CLB の熱処理で水素化が進んだも のでは，重質化が起こらず逆に軽質化が起こる事実と 一致している ${ }^{9)}$ 。

以上の結果より，ボトム循環系では，溶剤留分系に 比べて蒸留過程での残渣の重質化を回避しつつ, より 高い温度まで蒸留を行い，一層の液化油回収率の向上 をはかることが可能と考えられた。これは, 原料組成

(ボトム循環の有無) によって, 蒸留温度の最適点が 異ることを示唆するものである。

\section{4 残渣の流動性}

Fig. 5 に溶剂留分系生成液（Run-A）のフラッシュ 蒸留によって得られた生成液残渣の粘度の温度依存性 を示す。蒸留温度の上昇に伴って, 残渣の粘度は急激 に上昇したが, 温度依存性はいずれもほぼAndrade 型の式で表せた。しかし, 蒸留温度が $287^{\circ} \mathrm{C}$ から $305^{\circ} \mathrm{C}$ まで約 $20^{\circ} \mathrm{C}$ 上がることによって, $200^{\circ} \mathrm{C}$ の粘度は約 $10^{3}$ から $10^{5} \mathrm{mPa} \cdot \mathrm{S}$ と 2 桁上昇し, この差は粘度の温度

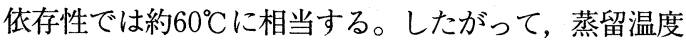
を上げることによって，残渣の流動性は急激に低下し， 蒸留塔からの抜き出しか難しくなるものと考えられる。

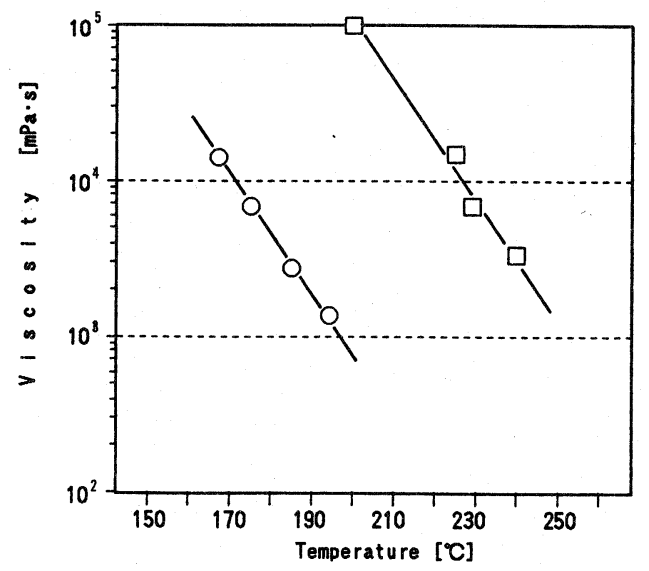

Fig.5 Relationship between Temperature and Viscosity of Bottom (RunA/Flash Distillation)

$\mathrm{O}$ : Distillation temperature of $287^{\circ} \mathrm{C}$

$\square$ : Distillation temperature of $305^{\circ} \mathrm{C}$
この残渣の組成による粘度変化を表す指標として, PI 成分 (灰分) の影響が無視できる場合 BI-PS/BS 比が 有効であることがわかっている ${ }^{12)}$ 。そこで, 今回 PI 成分も含めた指標として, 残渣の $\mathrm{BI} / \mathrm{BS}$ 比と粘度の 関係を調べた。 200 C における結果を Fig. 6 に示す。 この指標を用いればASTM-D1160とフラッシュ蒸留 と装置が異なり，かつ，蒸留温度が異なっても，原料 溶郕が溶剤留分 (b.p.180-420ㄷ) であればほぼ同一 の直線で整理でき, 溶剤留分系については蒸留温度の 上昇に伴う残渣の流動性の低下を予測することができ る。しかし, ボトム循環系の残渣では溶剤留分系に比 べて同じ BI/BS 比であっても粘度が高いことが明ら かとなった。これは，前述のようにBS あるいは BI-PS 成分の性状が原料溶剂のボトムの有無によって 変化し，ボトム循環系で生成した HI-BS および BI-PS 成分の分子量が大きいためと考えられる。以上 の結果より，残渣の変質（重質化）が少ないという観 点からはボトム循環系（特に BCL モード）の方が蒸 留温度を高め, さらなる液化油の回収をはかることが 可能となるものの, 残渣粘度が高く流動性の観点では より取扱いが厳しくなるものと考えられた。したがっ て，蒸留条件の設定にあたっては，この残渣の流動性 を考慮した決定が必要となろう。

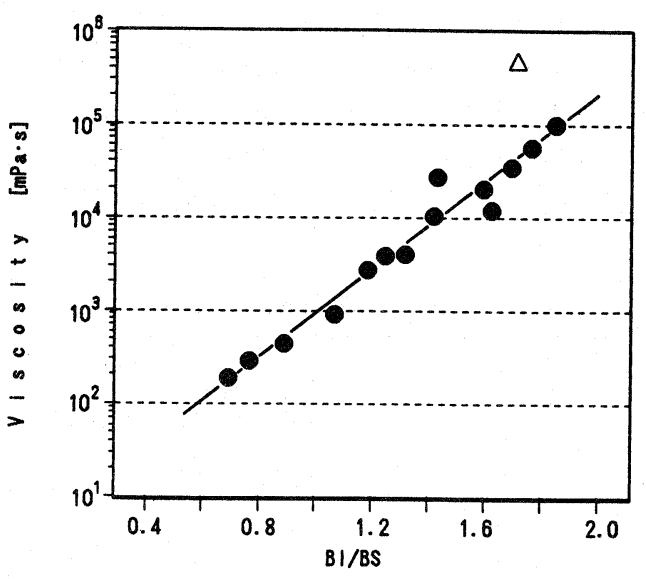

Fig.6 Relationship between BI-PS/BS of Bottom and Its Viscosity (at $200^{\circ} \mathrm{C}$ )

- Recovered bottoms from Run A and B at $287-323^{\circ} \mathrm{C}$

$10 \mathrm{mmHg}$ by ASTM-D1160 and flash distillations

$\triangle$ : Recovered bottom from RunC at $305^{\circ} \mathrm{C}$, $10 \mathrm{mmHg}$ by Flash distillation 


\section{4. まとめ}

連続装置によってビクトリア褐炭を組成の異る原料 溶剂で液化した生成液について残渣の収率とその性状 に与える蒸留温度の影響を調べた結果, 以下のことが 明らかとなった。

1 ) 蒸留温度を $10 \mathrm{mmHg}$ で $315^{\circ} \mathrm{C}$ (常圧換算 $484^{\circ} \mathrm{C}$ ) 程 度まで高くすることによって, 留出油（溶剂留分） のみを原料溶剂とした場合, 残渣中の HS 成分のほ とんどを留出油として回収でき, 著しく液化油（留 出油）回収率を向上させうることがわかった。しか し, 蒸留温度が高くなるに従い残渣が徐々に重質化 することもわかった。

2) ボトム循環系で得られる蒸留残渣はHS 成分の含 有率が高く, 溶剂留分系と比べて, 蒸留温度を高く してさらに液化油（留出油）回収率を向上させうる ことがわかった。また，このとき残渣の重質化は起 こらず，むしろ軽質化が起こることがわかった。こ れは, ボトム循環系溶剂で生成した重質物中に水素 供与性の高い HS 成分が多く, かつ, HI-BS, BI-PS 成分の分子量が大きく, 熱的に安定なもので あるためと考えられた。

3) 蒸留温度が高くなると急激に残渣の粘度が上がり, かつ, ボトム循環系の残渣の方が溶剤循環系の残渣 より粘度が高いことがわかった。

以上の結果は, 原料溶剂性状（特にボトム循環の有 無）によって生成液からの重質物の留出挙動と残渣の 性状の変化が異なり, 液化油の回収率および残渣の重 質化の有無とその流動性からみて, 最適条件が異なる ことを示唆するものであった。

(謝 辞)

本研究は新エネルギー・産業技術総合開発機構 （NEDO）の委託により実施したものであり，発表を 許可いただいた NEDO と, 実験・分析を担当してい
ただいた(株)神戸製鋼所・開発実験センターの皆様に 感謝致します。

\section{文献}

1 ）富永博夫, 神谷佳男, 「有機化学プロセス」（丸 善) p.209 (1981)

2 ）杉山勇夫, 佐藤孝志, 小林正俊, 中川朝之, 坂輪 光弘, 井口憲二, 山本久敬, 第28回石炭科学会議 発表論文集, p.355（1991）

3 ）増田 薰, 奥山憲幸, 平野龍夫, 大隈 修, 松村 哲夫, 第29回石炭科学会議発表論文集, p.268 (1992)

4 ）兼子隆雄, 䔖山陽一, 松村哲夫, 北村義則, 大隈 修, 日エネ誌，72，970（1993）

5 ）大隈 修, 矢内俊一, 平野龍夫, 松村哲夫, 日工 市誌, 72, 179 (1993)

6 ) 例えば, 大江修造,「蒸留工学」第 4 章（講談社 サイエンティフィク，1990)

7 ) Okuma, O., Saito, K., Kawasima, A., Okazaki, K. and Nakako, Y., Fuel Processing Technology, 14, 23 (1986)

8 ）平野龍夫, 大隈 修, 前 一広, 斉藤海三郎, 中 子敬夫, 第 22 回石炭科学会議発表論文集, p.88 (1985)

9) 持田 勲, 油布 淳, 坂西欣也, 趙 興哲, 大隈 修，平野龍夫，燃協誌，67，413 (1993)

10）立花茂雄, 美藤 裕, 大隈 修, 斉藤海三郎, 中 子敬夫, 第23回石炭科学会議発表論文集, p. 337 (1986)

11）神谷佳男, 第27回石炭科学会議発表論文集, p.1 (1990)

12) Okuma, O., Mae, K., Hirano, T. and Nakako, Y., Fuel Processing Technology, 19 ,165 (1988) 


\section{Effects of Distillation Temperature and Feed Solvent on Yield and Properties of Heavy Liquefaction Product from Victorian Brown Coal}

Tatsuo HIRANO ${ }^{* 1}$ and Osamu OKUMA ${ }^{* 2}$

$\left(\begin{array}{ll}* 1 & \text { Nippon Brown Coal Liquefaction Co., Ltd. } \\ * 2 & \text { Polymer \& Chemical Technology Laboratory, Kobe Steel, Ltd. }\end{array}\right)$

SYNOPSIS : - In a direct coal liquefaction process, in addition to the liquefaction condition, the distillation condition of the liquid product is an important factor to develop the process because it strongly affects the properties and yields of the distillate and bottom. Therefore, this paper investigates the effects of the vacuum distillation temperature on the yields and properties of the bottom and distillate, using the liquid products obtained from the primary hydrogenation section of the two-stage Victorian brown coal liquefaction (BCL) process with various feed solvents.

When recycled distillate (b. p. $180-420^{\circ} \mathrm{C}$ ) was used as a feed solvent, almost all of the $\mathrm{n}$-hexane solubles (HS) in the heavy product were distillable up to a temperature of ca. $315^{\circ} \mathrm{C}$ at $10 \mathrm{mmHg}$. As a result, the distillate yield increased with the temperature. However, the preasphaltenes also increased gradually with the temperature. On the other hand, when the solvent containing a bottom derived from primary and/or secondary hydrogenation was used as a feed solvent, the HS in the bottom remained at the same temperature $\left(315{ }^{\circ} \mathrm{C}\right)$, and the amount of preasphaltenes was constant. These differences were explained by the fact that the HS and asphaltenes derived from the bottom-containing solvent were more hydrogenated and stabilized, and their molecular weight was larger than that derived from the distillate solvent. It is also found that the viscosity of the bottom from the bottom-containing solvent was higher than that from the distillate solvent.

\section{Key Words}

Brown coal liquefaction, Feed solvent, Distillation temperature, Properties of bottom 